\title{
Elk Use of Winter Range as Affected by Cat- tle Grazing, Fertilizing, and Burning in Southeastern Washington
}

\author{
JON M. SKOVLIN, PAUL' J. EDGERTON, AND BURT R. MCCONNELL
}

\begin{abstract}
A study of ways to increase winter use by elk of Pacific bunchgrass foothill range in southeastern Washington employed fertilizing and rangeland burning, with and without spring cattle grazing. First-year response of elk to fertilizer applied in fall (56 kg N/ha) was a $49 \%$ increase in use; however, no significant carry-over effect was noted in subsequent years. Fall burning to remove dead standing litter and enhance forage palatability provided no increase in elk use in winter. Intensive cattle graxing in spring to promote regrowth did not increase elk use. In fact, cattle grazing decreased winter elk use by $28 \%$ in 1 of the 3 years studied. The cost effectiveness of increasing elk use by fertilizing appeared marginal except perhaps in special situations. A discussion of forage allocation to both elk and cattle is presented.
\end{abstract}

Rocky Mountain elk (Cervus elaphus nelsoni) ${ }^{1}$ have rapidly gained importance for providing hunting recreation and income revenues in the recent decade. About one-half million hunters harvest over 100 thousand elk. annually in the 11 Western States (Oertle 1977). Although demand for hunting is increasing, winter range is diminishing due to land development and poor range forage conditions (Klemmedson 1967).

Studies have shown that animal distribution and forage production can be increased by rangeland fertilization (Smith and Lang 1958, Cook 1965, Geist et al. 1974). Rangeland burning has also been found to increase ungulate use (Duvall and Whitaker 1964, Kruse 1972) by improving quality (Aldous 1934), availability (Vogl 1965), and palatability (Daubenmire 1968) of forage.

Improving big-game winter range by grazing cattle has been the subject of considerable debate. For example, investigators have suggested that grazing cattle in summer can improve forage for elk in winter (Anderson and Scherzinger 1975) and that heavy cattle grazing in fall attracts deer use in spring (Willms et al. 1979). Others have reported that cattle grazing in summer diminishes elk use (Blood 1966, Skovlin et al. 1968) and therefore may cause competition (Mackie 1970) or even be counterproductive to providing optimum elk winter range (Snyder 1969).

Before human settlement, winter elk range included the valley lowlands and adjacent mountain foothills which are now in private ownership and used for crops or spring-fall cattle grazing. Public acquisition of critical winter range has often been used to reduce conflicts and assure sustained production of winter forage for elk.

Typical of such a winter range in the interior Pacific Northwest is the William T. Wooten Habitat Management Area (Wooten area) ${ }^{2}$

\footnotetext{
The authors are, respectively, range scientist, research wildlife biologist, and research wild life biologist (retired), located at the Pacific Northwest Forest and Range Experiment Station, Range and Wildlife Habitat Laboratory, USDA-FS, Route 2, Box 2315, La Grande, Ore. 97850.

The authors express their appreciation to the Washington State Department of Game for providing land, facilities, and maintenance of the research installation. Manuscript received October 28, 1981.
}

'Formerly (Cervus canadensis nelsonii).

2Formerly Wooten Wildlife Recreation Area and Wooten Game Range.

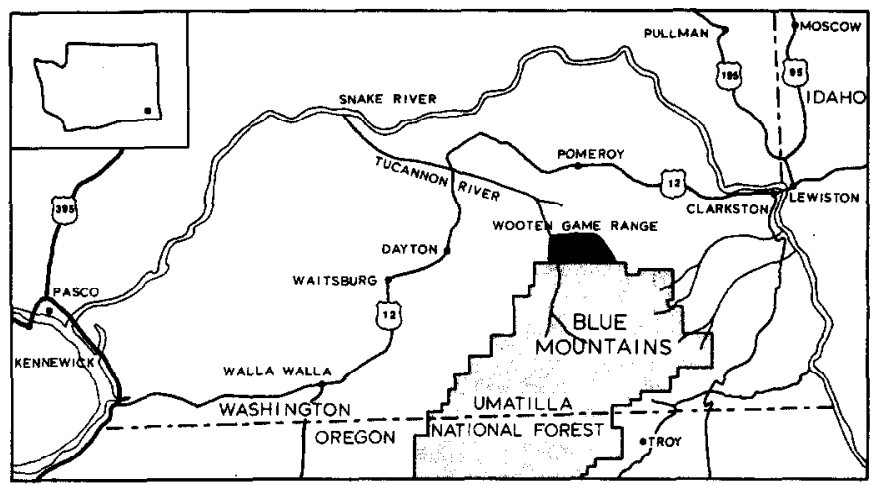

Fig. 1. The Wooten Habitat Management Area lies along the transitional foothill zone at the extreme northern end of the Blue Mountains.

operated by the State of Washington Department of Game (Fig. 1). It is located in the northern foothills of the Blue Mountains in the extreme southeastern corner of Washington $24 \mathrm{~km}$ south of Pomeroy. In 1970, the Washington State Department of Game entered into a cooperative study with the Pacific Northwest Forest and Range Experiment Station to investigate techniques for making herbaceous forage on the Wooten area more attractive to wintering elk.

Three rangeland treatments were compared: (1) annual spring cattle grazing, (2) a single fall application of fertilizer, and (3) a single fall prescribed burning treatment. This paper reports response of elk during 3 winters following treatment.

\section{Study Area}

The 5,225-ha Wooten area was established in 1940 to provide winter habitat and forage for big game, primarily elk, in a narrow transitional foothill zone between the rolling hills of Palouse Prairie to the north and the mixed conifer upland forest types of the Blue Mountains to the south.

In the past, this area was logged, grazed by cattle, and parts were farmed. There has been no permitted cattle grazing since the mid 1940's. A high, game-proof fence erected in the mid 1960's along the northeast side of the area concentrates wintering elk on the abundant, natural forage and alleviates damage on adjoining range and farmland. The Umatilla National Forest provides ample forested summer range for elk.

Annual precipitation at Wooten area headquarters, $600 \mathrm{~m}$ above mean sea level, averaged $76 \mathrm{~cm}$ during recent years (1974-1979). A 10-year average at the nearest representative long-term weather station in the Walla Walla watershed was $109 \mathrm{~cm}$. Annual precipitation on the ridgetop study area is estimated to be about $100 \mathrm{~cm}$, one-third of which falls as snow between December and March.

The 60-ha study site lies on top of Ables Ridge and is surrounded by a 610-ha fenced cattle pasture (Fig. 2). The ridgetop is an open grassland about $1,200 \mathrm{~m}$ long by $400 \mathrm{~m}$ wide. It is nearly level, with 

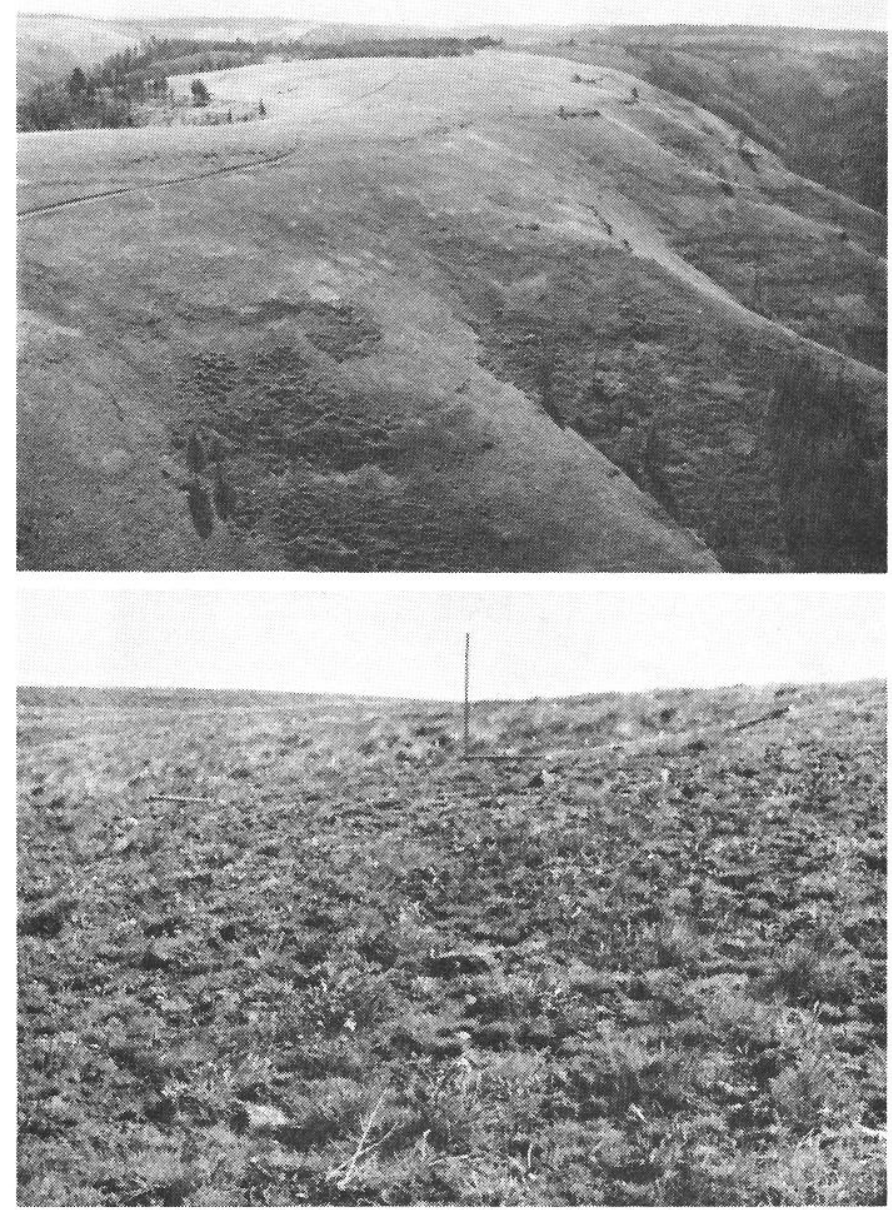

Fig. 2. The Ables Ridge study site and surrounding canyon lands (above) support a Pacific bunchgrass community in good condition (below). The "let-down" fence separates spring cattle grazing (foreground) from protected range (background) for comparing subsequent winter use by elk.

an upper elevation of about $1,200 \mathrm{~m}$. The ridge drops $150 \mathrm{~m}$ in elevation in a northwesterly direction along the course of the study area. Water for cattle grazing in spring is plentiful on the ridgetop and in adjacent canyon bottoms.

Deep V-shaped canyons and open ridges characterize the surrounding landscape; drainages flow northwest. Open bunchgrass slopes on steep southwesterly exposures are often free of snow making excellent winter forage areas for elk. A mixed forest of Douglas-fir (Pseudotsuga menziesii), western larch (Larix occidentalis), and scattered ponderosa pine (Pinus ponderosa) on northeast exposures provides thermal and hiding cover below the open, grass-covered ridgetop. During the study, an estimated 400 elk wintered on the Wooten area, many of which spent considerable time on Ables Ridge ${ }^{3}$.

\section{Soils and Vegetation}

The soils of Ables Ridge have been classified in the Waha and Rockland series (USDA Soil Conservation Service 1968). The more sloping, geologically eroded uplands grade into a hummockswale complex of shallower Rockland soil between areas of deeper Waha soil, which is characterized by a "biscuit scabland" macrorelief.

Waha is by far the dominant soil series on this area. It is a medium-textured, well-drained soil between 45 and $60 \mathrm{~cm}$ deep over an old basaltic land surface and was formed from weathered basalt and loess. The surface soil is very dark brown to black silt

${ }^{3}$ Personal communication with Allen Parmanteer, Wooten Habitat Managemen Area Manager, March 1981. loam from 8 to $13 \mathrm{~cm}$ thick; the subsoil is a brown clay loam containing 30 - to 50 -percent basalt by volume. The associated Rockland series, interspersed at the edges of the ridge between stringers of Waha, is a heavy textured soil between 5 and $25 \mathrm{~cm}$ deep. It has a rocky surface, some exposed basalt outcropping, and small pockets of deeper soil.

Deep Waha soils support a herbaceous layer of perennial bunchforming grasses dominated by bearded bluebunch wheatgrass (Agropyron spicatum) 4 and Idaho fescue (Festuca idahoensis); prairie junegrass (Koeleria cristata) and Kentucky bluegrass (Poa pratensis) are also common. Although Sandburg bluegrass (Poa secunda) and onespike oatgrass (Danthonia spicata) occur here, they dominate only in shallower swales.

Lesser amounts of wheatgrass and fescue occur in the Rockland swales. Forbs are seasonal with a succession of spring flowering species such as Douglas blueyed grass (Sisyrinchium douglasii), camas (Camassia quamash), balsamroot (Balsamorhiza hookeri), rush pussytoes (Antennaria luzuloides), buckwheat (Eriogonum heracleoides), and western yarrow (Achillea millifolium lanulosa). Isolated clumps of snowberry (Symphoricarpos rotundifolius) occur within ridgetop grassland communities.

\section{Rangeland Status}

Buechner (1952) reported that his Ables Ridge elk study area (570 ha) was "not in good condition" based on inventory work in 1949-1950. He noted, however, that it had been improving since cattle grazing had ceased 5 years earlier. Estimated overall herbage production in 1949-50 was about $335 \mathrm{~kg}$ per ha, two-thirds of which was wheatgrass. During that 5 -month winter-one of the severest on record-elk removed about $80 \%$ of the herbage. In 1980 , estimates placed Ables Ridge in good to excellent condition and the surrounding canyon land in fair condition. ${ }^{5}$

\section{Methods}

This 3-year study involved a design of regulated cattle grazing, rangeland fertilizing, and controlled burning as a means of making lightly used bunchgrass more attractive to wintering elk.

\section{Design}

The experiment was a split-split-plot design with 3 whole plots randomly assigned to grazing by cattle and 3 assigned to no grazing. Each whole plot was divided into 3 sections which were randomly assigned to fertilizing, burning, and control treatments (Fig. 3) for 3 years of measurement. A 15-m untreated buffer strip surrounded each treatment plot.

Three whole-plots, about 9.3 ha each, were protected from spring cattle grazing with "let-down" fences-fences that can be raised or lowered to provide temporary protection. The other 3 were open to cattle grazing from mid-April to early June in 1971, 1972, and 1973. A grazing rate of about 2.4 ha of range per animal unit month $(\mathrm{AUM})^{6}$ assured substantial use on major gráss species. This season and level of grazing was to obtain maximum regrowth for subsequent winter elk use. Each fall, cattle fences were let down so that elk had unrestricted movement throughout all plots during their normal 3- to 4-month winter use period. The fences were raised again each spring after elk had migrated to summer range but before cattle arrived.

Fertilization consisted of a single application of Ortho Unipel ${ }^{7}$ $\left(27 \% \mathrm{~N}, 12 \% \mathrm{P}_{2} 0_{5}, 0 \% \mathrm{~K}, 4 \% \mathrm{~S}\right)^{8}$ in the fall of 1971 . It was applied at a rate of $56 \mathrm{~kg}$ of $\mathrm{N}$ per hectare with a commercially equipped Bell helicopter.

\footnotetext{
${ }^{4}$ Nomenclature follows that of Garrison et al. (1976).

${ }_{5}^{5}$ Personal communication with Buz Houtz, District Conservationist, Soil Conservation Service, Pomeroy, Washington, March 1980.

${ }^{6}$ Normally considered one mature cow $(454 \mathrm{~kg})$ or the equivalent; stocking here was with mature cows and their spring calves.

The use of trade names does not constitute endorsement where the use of an equally suitable product would be as acceptable.

${ }^{8}$ Composition was recommended on the basis of soil pot tests. The phosphorus was added mainly to increase palatability; presumably it increases sugar content in the forage (Staten 1949).
} 


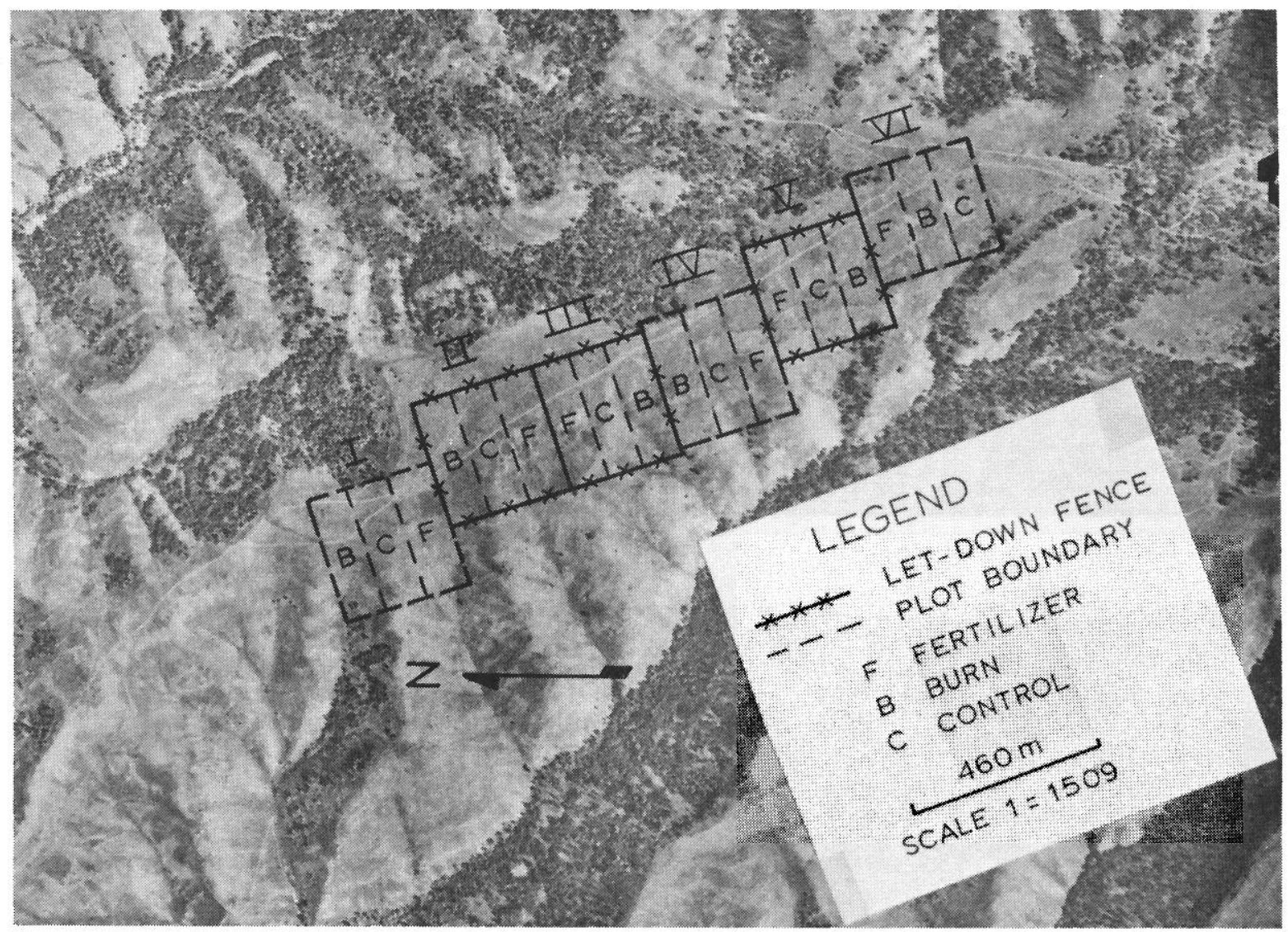

Fig. 3. Six replicates of fertilized, burned, and control plots were separated by "let-down" cattle fence to provide 3 whole plots grazed by cattle and 3 protected plots for comparing elk winter range use.

Burning was applied during late fall of 1971. Fire breaks were sprayed around burn plots with the desiccator Paraquat ${ }^{7}$ during the summer of 1971. The subsequent fall burn was patchy, however. The remaining unburned areas were fired with a propane field burner pulled by 4-wheel drive vehicle on gentler slopes; propane hand torches with backpack tanks were used on steeper slopes.

\section{Measurement and Analysis of Response}

Elk use in response to treatments was measured by pellet group counts (Neff 1968). Twelve transects were randomly located on a common baseline along one side of each whole-plot. Each transect line extended across all 3 split plots (burned, fertilized, and control). Thus, pellet groups were counted on 12 transects 76.2 - by 2.12-m (0.194 ha sample) in each split plot. Groups were counted and sprayed with paint on all plots early each spring after elk use but before cattle grazing.

Spring pellet counts measured elk use in the winters of 1971-1972, 1972-1973, and 1973-1974. Two pellet counts were also made before treatments. The first, representing an estimated accumulation of 3 years, was made at the time transects were installed in the fall of 1969. The second, representing only one winter, was in the spring of 1970 . The 2 counts were combined and averaged to represent a 4-year calibration period. These pretreatment data were then used as covariates in the analysis to adjust for elk-use patterns prior to the study. A pellet count was made in the spring of 1975, a year after cattle grazing, to see whether reverse effects in elk use might be detected.

Analysis of variance was used to determine whether counts varied significantly between treated and untreated areas. Scheffe's multiple comparison procedure was used to contrast adjusted treat ment means averaged over all years. Tukey's multiple comparison procedure contrasted treatment means for each of the 3 years.

Following the 1971 fall burning and fertilizer treatments, a forage utilization survey was conducted in late June of $1972 \mathrm{imme-}$ diately after spring cattle grazing, using the Ocular-Estimate-ByPlot method (Pechanec and Pickford 1937). This survey, together with a cow-chip count (Julander 1955), furnished information for cattle stocking adjustment and provided data to interpret elk use that might result from treatment combinations masked by uneven cattle grazing or for other interactions.

\section{Results and Discussion}

Spring cattle grazing had no significant effect on subsequent winter use by elk when averaged over all treatments and years (Fig. 4). Cattle grazing during the spring of 1972 , however, significantly $(P<0.01)$ reduced elk use by $28 \%$ during the second winter

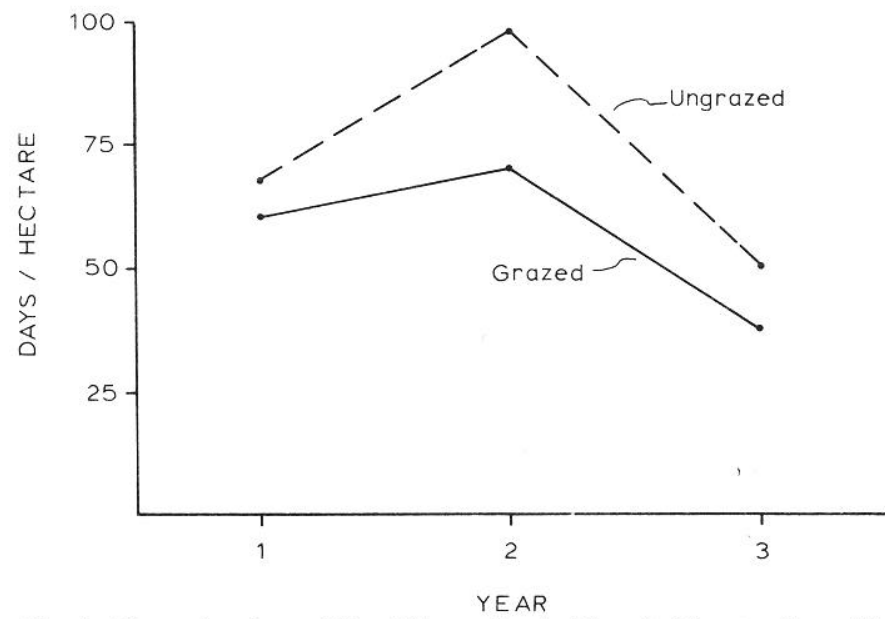

Fig. 4. Elk use in winter of foothill rangeland with and without spring cattle grazing. 
(1972-1973) - -the winter with least snow accumulations and heaviest elk use. Elk use during the other 2 winters also appeared to be less on range grazed by cattle than on ungrazed range, but these differences were not significant.

Fertilized range received significantly $(R<0.01)$ more elk use than either burned or untreated range during the first winter after treat ment (Fig. 5). Pellet group counts were $49 \%$ greater than on unfertilized range. The same rate of use occurred during the second winter, but differences between treatments were not significant. During the third winter, treatment had no apparent effect on level of elk use.

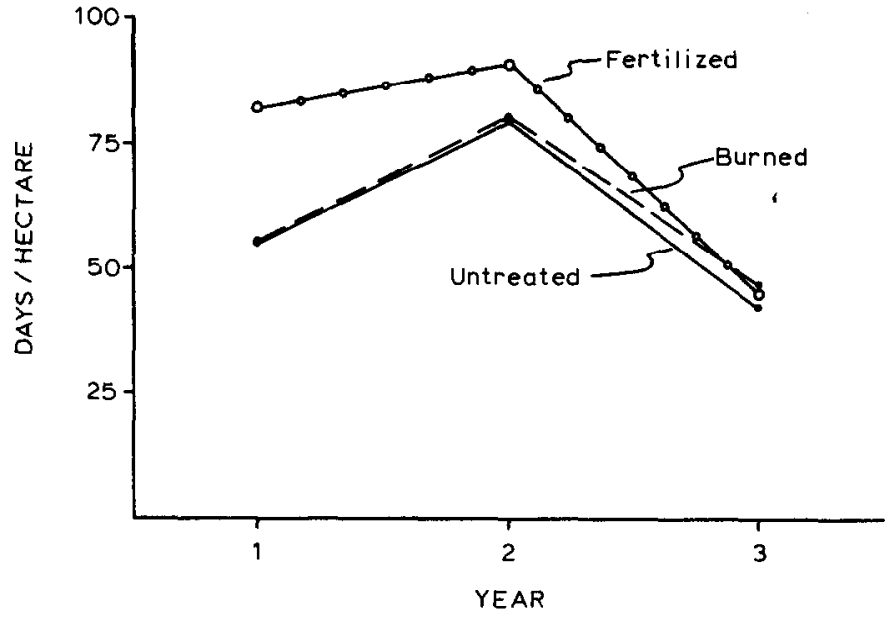

Fig. 5. Elk use in winter of fertilized, burned, or untreated foothill rangeland.

\section{Weather Patterns}

Figure 6 shows winter and spring precipitation at the nearest long-term weather station. The data provide an index to show accumulation and variations in growing season during the study. Elk use of Ables Ridge varied inversely with winter precipitation. During the winter with low precipitation and a light snow pack (1972-1973), elk use was higher than during the winter of 1973-1974 when a deeper snow pack forced elk to use lower canyon slopes.

\section{Timing of Treatment}

Grazing of cattle was done in spring 1971 before the fall fertilizer and burning treatments. Forage grazed by cattle in the spring on the plots assigned burning treatment in fall was consumed by fire before elk use the following winter. Therefore, the effects of cattle grazing on elk use that lst year were obscured by burning.

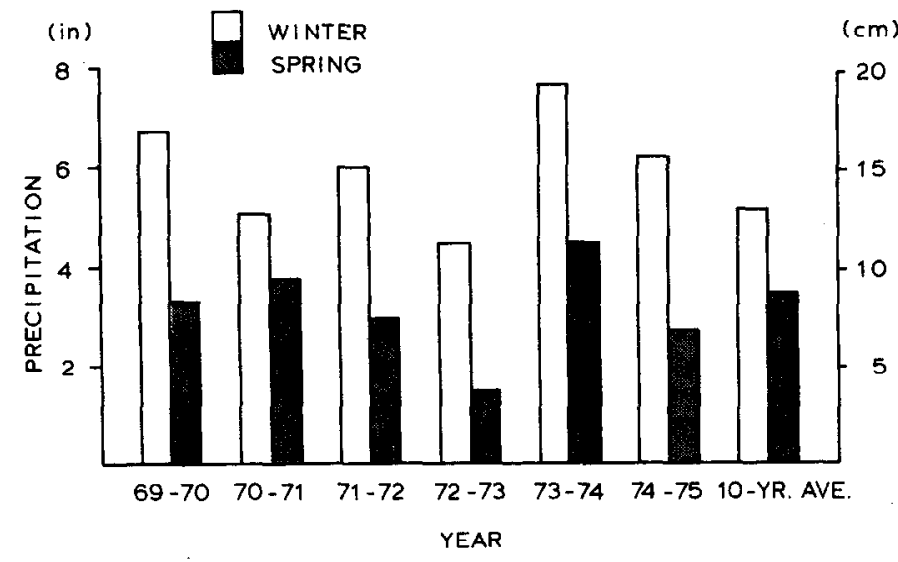

Fig. 6. Precipitation during winter (Dec.-Mar.) and spring (Apr.-June) in the Walla Walla watershed provides an index to snow depth and growing season variation throughout the years of study (1970-1974) together with the previous 10-year average.
Whether cattle grazing was heavier on fertilized or burned range in years 2 and 3 was not determined. From the literature, however, we suspect there was added cattle grazing on the fertilized, and perhaps, on the burned range (Smith and Lang 1958, Hooper et al. 1969, Baldwin et al. 1974).

\section{Fertilizer Effects}

Elk probably preferred the fertilized range in year 1 because nutrient levels of the forage was higher late in the season (Carpenter and Williams 1972) and because cattle had not yet grazed it extensively. Although nutrient content of the fertilized forage was not determined, other studies have shown that protein content and perhaps digestibility of dry matter is higher on fertilized than on non-fertilized range (Schlatterer 1974).

Carry-over from our single application of fertilizer may have produced greater forage yield and/or grazing by cattle during the next growing season (spring 1972). Cook (1965) found carry-over yield on seeded foothill range to be $30 \%$ and $10 \%$ for the second and third growing seasons after $45 \mathrm{~kg} / \mathrm{ha}$ of $\mathrm{N}$ was applied. Others have reported variable carry-over results for similar rates of $\mathrm{N}$ on foothill range (Patterson and Youngman 1960, Basile 1970, Pumphrey and Hart 1973).

It may be possible to increase elk use even more with higher rates of fertilizer than we applied, but we speculate that our findings would not have been greatly altered. Of the few reported studies on the effect of fertilizer rates, Brown and Mandery (1962) showed that forage use by elk in western Washington did not increase with rates of nitrogen above $16.8 \mathrm{~kg}$ per ha $(15 \mathrm{lb} \mathrm{N} / \mathrm{acre})$. In the southwest, however, Holt and Wilson (1961) found cattle use of forage increased 3,4, and 5 times over fertilized range in response to 28 , 56, and $112 \mathrm{~kg} \mathrm{~N}$ per ha $(25,50$, and $100 \mathrm{lb} \mathrm{N} / \mathrm{acre})$, respectively.

Fertilizer can produce a variety of effects on forage depending on season, rate, site, and soil moisture; however, it nearly always extends the period that forage remains green (Cook 1965, Baldwin et al. 1974, Geist et al. 1974). In this study the carry-over effect of fertilizer on forage quality or regrowth quantity was not sufficient to cause a real difference in elk use during the second or third winter after treatment.

\section{Effects of Burning}

Fall burning was expected to increase winter elk use, particularly on ungrazed plots. Studies have shown that fire may not improve the quality of new forage (Grelen and Epps 1967); but it does remove standing, dry litter which lowers palatability and acts as a barrier to grazing on new green forage (Vogl 1965, Wright 1974). Other workers have shown that when litter is burned, new spring growth is initiated several weeks earlier than on unburned rangeland (Ehrenreich 1959, Daubenmire 1968). For these reasons, both wild ungulates and livestock normally prefer previously burned range (Duvall and Whitaker 1964, Daubenmire 1968).

Greenup on our burned plots occurred several weeks in advance of that on unburned plots and should have provided sufficient time for elk to respond if they found the burned plots more attractive. Spring growth, particularly of Idaho fescue, on similar aspects throughout the Blue Mountains is generally available in February and March and often constitutes a large part of elk diet in late winter (Skovlin and Vavra 1979).

In this study, fall burning, after rains had begun, did not result in increased winter use by elk. Perhaps controlled burning in late summer, followed by substantial fall rains, would produce forage more attractive to elk. Fall rains, however, cannot be predicted with any certainty; and summer burning can be hazardous to plants, especially Idaho fescue (Conrad and Poulton 1966). Mortality can be particularly high if burned areas are subject to unregulated grazing or if a period of drought follows burning (Pickford 1932). 


\section{Grazing Level}

In 1971, an average forage year, the prescribed level of cattle stocking resulted in forage use levels of:

$\begin{array}{lc}\text { Species } & \% \text { Use by Weight } \\ \text { ldaho fescue } & 42 \\ \text { Bluebunch wheatgrass } & 33 \\ \text { Sandberg bluegrass } & 4\end{array}$

Cattle were stocked at 2.4 ha of available range per AUM (610 ha for 250 AUM's); however, a cow-chip inventory taken during the 1972 elk pellet count indicated that actual use on the study plots was $1.1 \mathrm{ha} / \mathrm{AUM}(0.9 \mathrm{AUM} / \mathrm{ha})$. In view of the fact that $50 \%$ of the pasture had extremely steep $(\geq 60 \%)$, unusable slopes, concentrated use of the ridgetop by cattle was expected.

This concentration places cattle stocking at full capacity for Range Condition Standards (USDA Soil Conservation Service 1968) on Ables Ridge. Because early spring grazing occurs during the critical growing period, rotated deferment of grazing is necessary to maintain good range conditions over the long term (Stoddard 1946, Blaisdell and Pechanec 1949).

\section{Preference and Palatability}

Free ranging ruminants, especially wild species such as deer and elk, are believed to have intuitive and sensory capabilities that enable them to select high quality plants from whatever forage is available (Swift 1948, Krueger et al. 1974). Quality was probably the attraction for elk following the Ist year of fertilizer application; however, higher quality which may have resulted from cattlegrazing or burning treatments was not sufficiently attractive to elk to show real differences in winter use.

On another Blue Mountain elk winter range, light grazing by cattle in late spring and early summer has been suggested as the reason for increased winter use by elk (Anderson and Scherzinger 1975). It was postulated that regrowth following grazing, which is higher in nutrients than ungrazed forage, was available in winter and attracted elk in ever increasing numbers. The results of our field experiment, however, do not support this plausible hypothesis. We found moderate level cattle grazing did not promote increased winter elk use.

\section{Habitat Preference}

On Ables Ridge, elk preferred lower reaches (whole plot I) and cattle preferred upper reaches (whole plot VI). Compared to the upper ridge, the lower reach is narrower, steeper, rockier, with greater macrorelief, and probably less accumulated snow (see Fig. 2 and 3). Similar preferences by elk and cattle have been suggested by other workers (Jeffery 1963, Julander and Jeffery 1964, Nagle and Harris 1966, Reynolds 1966). On Ables Ridge, elk showed the same distribution pattern before, during, and after the 3-year grazing treatment, so spring levels of cattle use had no apparent effect on elk habitat selection in winter. It is also likely that elk grazing did not affect patterns of cattle use in spring, because by the time cattle began grazing in mid-April, elk use was obscured by lush, new growth.

Recent reports evaluating pellet group sampling show that distribution may not be a reliable index to habitat preference because activities between habitats may produce large variation in defecation rate (Collins and Urness 1981, Skovlin 1982). We assume in this study, however, that the rather uniform soil, range site, and condition of the wheatgrass/fescue community constituted but one habitat (see Study Area) and that the predominant response activity to treatments was grazing.

\section{Management Considerations}

Our findings suggest that fertilizing and, to a lesser extent, spring cattle grazing, may have practical application in the management of elk winter ranges under certain conditions; fall burning did not increase elk use in winter.

\section{Fertilization}

Where sufficient forage is available to meet normal winter requirements, fertilizing to increase elk use is not cost efficient (Bayoumi and Smith 1976). When an increase in elk numbers is desirable and additional winter range is not available, fertilization may compare favorably in cost with supplemental feeding or purchase of additional rangeland. Fertilization may also be justified as a means of attracting elk away from agricultural lands where they damage high-value crops such as orchards. Fertilization could also be used to improve nutrient content and digestibility of forage on poor quality range where elk mortality is common during winter stress.

Variable response of range plants to fertilizer has been reported (Basile 1970, Pumphrey and Hart 1973, Schlatterer 1974). The ecological consequences of fertilizing must also be considered, particularly at higher application rates. In nearby areas of southeastern Washington, rates of $N$ higher than $45 \mathrm{~kg}$ per ha favored annual grasses to the detriment of perennial bunchgrasses (Patterson and Youngman 1960). On summer range with similar composition in northeastern Oregon, Baldwin et al. (1974) cautioned that very high rates of fertilizer could not only cause retrogressive shifts in plant composition but also result in nitrate poisoning of animals.

The cost of fertilizing might be defrayed by renting pasture for light cattle grazing in spring, without significantly lowering elk use in winter. Higher rent might be justified for pastures that have been fertilized. It is possible that the same benefits to both elk and cattle found in our study might result from somewhat lower rates of fertilizer than we used. To managers who consider fertilizing, we recommend a simplified field trial to determine feasibility under different range conditions. In view of the uncertainties of plant response, weather, which is unknown from year to year, and its effects on elk migration, as well as the fact that similar management alternatives such as other forage improvement practices, fencing, feeding, or hazing for damage control are available, the benefits and costs of fertilizing elk winter range seem marginal.

\section{Dual-Use Strategy}

If properly allocated, cattle grazing in spring coupled with elk use in winter can produce a high output of animal biomass from similar foothill range. Elk use in winter has only a slight physiological impact on dormant plants (Stoddart 1946, Blaisdell and Pechanec 1949) and can often be increased without impairing range condition. The central concern where elk and cattle prefer the same forage species-primarily Idaho fescue in our case-is that the forage base not be depleted.

Spring cattle-stocking during this experiment probably exceeded the sustained allowable.level, judging from the difference in estimated grazing capacity and actual use. A monitoring system, such as that proposed by Smith (1965), showing when allowable use exceeds plant tolerance is essential. Also necessary is a scheme for monitoring soil impacts to maintain cover minimums, as suggested by Packer (1963). Buechner (1952) reported that the 0.6 elk months per hectare using this area in 1949-1950 may not have exceeded proper forage use but cautioned that, in view of potential for soil erosion on the steep, foothill slopes during early spring, there were too many elk.

Based on our findings, a practical strategy for producing both plants and animals would allow 2 months of cattle stocking at 1.4 ha/ AUM (30 to $40 \%$ less than the trial rate) on two pastures, with rotated grazing deferment alternating between May 1 one year and June 1 the next. This should: (1) provide a slight improvement in the fescue-wheatgrass stand, (2) permit near optimum elk use in most winters, (3) allow for a modest increase in numbers of wintering elk, and (4) permit cattle to utilize surplus forage at the peak of nutrient quality. Our research results showed, however, that highest elk use in winter was obtained where there was no grazing by cattle.

\section{Conclusions}

Concentrated spring cattle grazing on foothill range did not promote forage conditions that improved winter use by elk. Moreover, cattle grazing reduced elk use by $28 \%$ in 1 of the 3 years 
studied. A light level of cattle stocking in spring probably would have made no real difference in winter use by elk.

We found that fertilizing in fall increased elk use in winter by 49\% the first winter after application, but no carry-over effect was apparent in the next 2 years. We cannot recommend fertilizing as a cost effective practice, however, except under extreme or high-risk situations.

Rangeland burning in fall did not increase elk use in winter to any measurable degree. The literature suggests that a hotter fire that removes all fuel, such as from summer burning, might damage Idaho fescue, the most desirable forage species for elk. Therefore, we cannot recommend this practice on the basis of information available.

If forage supplies exceed the winter needs of elk, and range condition is acceptable, light cattle grazing in spring or early summer might be maintained without adverse effects. Nevertheless, our findings showed that cattle grazing diminished winter elk use significantly in 1 of the 3 years studied.

\section{Literature Cited}

Aldous, A.E. 1934. Effect of burning on Kansas bluestem pastures. Kansas Agr. Exp. Sta. Tech. Bull. 38.

Anderson, E. Willam, and Richard J. Scherzinger. 1975. Improving quality of winter forage for elk by cattle grazing. J. Range Manage. 28:120-125.

Baldwin, Donald M., Newton W. Hawkinson, and E. William Anderson. 1974. High-rate fertilization of native rangeland in Oregon. J. Range Manage. 27:214-216.

Basile, Joseph V. 1970. Fertilizing to improve elk winter range in Montana. USDA. Forest Serv. Res. Note INT-113.

Bayoumi, Mohamed A., and Arthur D. Smith. 1976. Response of big game winter range vegetation to fertilization. J. Range Manage. 29:44-48.

Blaisdell, James P., and Joseph F. Pechanec. 1949. Effects of herbage removal at various dates on the vigor of bluebunch wheatgrass and arrowleaf balsam root. Ecology 30:298-305.

Blood, Donald A. 1966. Range relationships of elk and cattle in Riding Mountain National Park, Manitoba. Can. Wildl. Serv., Wildl. Manage. Bull., Ser. 1, No. 19.

Brown, E. Reade, and John H. Mandery. 1962. Planting and fertilization as a possible means of controlling distribution of big game animals. J. For. 60:33-35.

Buechner, Helmut K. 1952. Winter-range utilization by elk and mule deer in southeastern Washington. J. Range Manage. 5:76-80.

Carpenter, Len H., and Gary L. Williams. 1972. A literature review on the role of mineral fertilizers in big game range improvement. Colorado Div. Game, Fish and Parks Spec. Rep. No. 28.

Collins, W.B., and P.J. Urness. 1981. Habitat preferences of mule deer as related by pellet-group distribution. J. Wildl. Manage. 45:969-972.

Conrad, C. Eugene, and Charles E. Poulton. 1966. Effect of a wildfire on Idaho fescue and bluebunch wheatgrass. J. Range Manage. 19:138-141.

Cook, C. Wayne. 1965. Plant and livetock responses to fertilized rangelands. Utah State Univ. Agr. Exp. Sta. Bull. 455.

Daubenmire, R. 1968. Ecology of fire in grasslands. p. 209-266. In: Advances in ecological research, edited by J.B. Cragg. Academic Press, London and New York.

Duvall, V.L., and L.B. Whitaker. 1964. Rotation burning: a forage management system for longleaf pine-bluestem ranges. J. Range Manage. 17:322-326.

Ehrenreich, John H. 1959. Effect of burning and clipping on growth of native prairie in Iowa. J. Range Manage. 12:133-137.

Garrison, G.A., J.M. Skovlin, C.E. Poulton, and A.H. Winward. 1976. Northwest plant names and symbols for ecosystem inventory and analysis. 4th ed. USDA-FS, Pacific Northwest Forest and Range Exp. Sta., Portland, Ore.

Geist, J. Michael, Paul J. Edgerton, and Gerald S. Strickler. 1974. "Yukky to Yummy"-with fertilizers. Rangeman's J. 1:30-41.

Grelen, H.E., and E.A. Epps, Jr. 1967. Season of burning affects herbage quality and yield on pine-bluestem range. J. Range Manage. 20:31-33.

Holt, Gary A., and David G. Wilson. 1961. The effect of commercial fertilizers on forage production and utilization on a desert grassland site. J. Range Manage. 14:252-256.

Hooper, Jack F., John P. Workman, Jim B. Grumbles, and C. Wayne Cook. 1969. Improved livestock distribution with fertilizer-a preliminary economic evaluation. J. Range Manage. 22:108-110. effery, Duane Eldro. 1963. Factors influencing elk distribution on Willow Creek summer range, Utah. M.S. thesis. Utah State Univ., Logan.

Julander, Odell. 1955. Determining grazing use by cow-chip counts. J. Range Manage. 8:182.

Julander, Odell, and Duane E. Jeffery. 1964. Deer, elk, and cattle range relations on summer range in Utah. 29th North Amer. Wildl. Conf. p. 404-413.

Klemmedson, James 0. 1967. Big-game winter range-a diminishing resource. Trans. 32nd North Amer. Wildl. and Nat. Resour. Conf. p. 259-269.

Krueger, William C., William A. Laycock, and Donald A. Price. 1974. Relationships of taste, smell, sight, and touch to forage selection. J. Range Manage. 27:258-264.

Kruse, William H. 1972. Effects of wildfire on elk and deer use of a ponderosa pine forest. USDA-FS. Res. Note RM-226. Rocky Mt. Forest and Range Exp. Sta., Fort Collins, Colo.

Mackie, Richard J. 1970. Range ecology and relations of mule deer, elk, and cattle in the Missouri Breaks, Montana. Wildl. Monogr. No. 20.

Nagle, John P., and Grant A. Harris. 1966. Grazing compatibility of cattle and elk on mountain ranges. 10th Internat. Grassland Congr. Proc., Sect. 4, Pap. No. 44. p. 994-997.

Neff, Don J. 1968. The pellet-group count technique for big game trend, census, and distribution: a review. J. Wildl. Manage. 32:597-614.

Oertle, V. Iee. 1977 . Elk hunting today-a comparison of 11 states. Outdoor Life, August. p. 85, 124-125.

Packer, Paul E. 1963. Soil stability requirements for the Gallatin elk winter range. J. Wildl. Manage. 27:401-410.

Patterson, J.K., and V.E. Youngman. 1960. Can fertilizers effectively increase our range land production? J. Range Manage. 13:255-257.

Pechanec, Joseph F., and G.D. Pickford. 1937. A comparison of some methods used in determining percentage utilization of range grasses. J. Agr. Res. 54:753-765.

Pickford, G.D. 1932. The influence of continued heavy grazing and of promiscuous burning on spring-fall ranges in Utah. Ecology 13:159-171.

Pumphrey, F.V., and R.D. Hart. 1973. Fertilizing rangeland in northeast Oregon. Oregon State Univ. Agr. Exp. Sta. Spec. Rep. 378.

Reynolds, Hudson G. 1966. Use of ponderosa pine forest in Arizona by deer, elk, and cattle. USDA-FS. Res. Note RM-63. Rocky Mt. Forest and Range Exp. Sta., Fort Collins, Colo.

Schlatterer, E.F. 1974. A partial literature review on the use of fertilizer to increase production on rangelands. Range Improv. Notes 19. USDA-FS, Intermt. Reg., Ogden, Utah.

Skovlin, Jon M. 1982. Habitat requirements and their evaluations. p. 369-413. In: Elk of North America: ecology and management. Jack Ward Thomas and Dale E. Toweill, eds. Wildlife Management Institute, and Stackpole Books, Harrisburg, $\mathbf{P a}$.

Skovlin, Jon M., Paud J. Edgerton, and Robert W. Harris. 1968. The influence of cattle management on deer and elk. Trans. 33rd North Amer. Wildl. and Nat. Resour. Conf. p. 169-18I.

Skovlin, Jon, and Martin Vavra. 1979. Winter diets of elk and deer in the Blue Mountains, Oregon. USDA-FS. Res. Pap. PNW-260. Pacific Northwest Forest and Range Exp. Sta., Portland, Ore.

Smith, Arthur D. 1965. Determining common use grazing capacities by application of the key species concept. J. Range Manage. 18:196-201.

Smith, D.R., and R.L. Lang. 1958. The effect of nitrogenous fertilizer on cattle distribution on mountain range. J. Range Manage. I1:248-249.

Snyder, Roy Owen. 1969. Forage competition between cattle and elk in the Grid Creek drainage of western Montana. M.S. thesis. Univ. Montana, Missoula.

Staten, H.W. 1949. Palatability trials of winter pasture crops and effect of phosphate fertilization on palatability. Oklahoma Agr. Exp. Sta. Tech. Bull. T-35.

Stoddart, L.A. 1946. Some physical and chemical responses of Agropyron spicatum to herbage removal at various seasons. Utah Agr. Exp. Sta. Bull. 324.

Swift, R.W. 1948. Deer select most nutritious forages. J. Wildl. Manage. 2: 109-110.

USDA Soil Conservation Service. 1968. Soil and water conservation plan, Wooten Game Range. USDA, Soil Conserv. Serv. Columbia County, Pomeroy, Wash.

Vogl, Richard J. 1965. Effects of spring burning on yield of brush prairie savanna. J. Range Manage. 18:202-206.

Wilms, W., A. McLean, R. Tucker, and R. Ritcey. 1979. Interactions between mule deer and cattle on big sagebrush range in British Columbia. J. Range Manage. 32:299-304.

Wright, Henry A. 1974. Range burning. J. Range Manage. 27:5-11. 